\title{
ЗАБІР КРОВІ 3 ВЕНИ: ОСНОВНІ ПРАВИЛА, СПОСОБИ, СУЧАСНІ ТЕХНОЛОГІЇ
}

\author{
В. А. Славопас \\ Приватний вищий навчальний заклад «Медичний коледж» м. Тернопіль
}

У статті висвітлено основні правила забору венозної крові, способи полегшення забору у пацієнтів 3 «проблемними» венами, описано сучасні технології пошуку та візуалізації вен.

\section{BLOOD SAMPLING FROM A VEIN: BASIC RULES, METHODS, MODERN TECHNOLOGY}

\author{
V. A. Slavopas
}

\section{Medical College, Ternopil}

The article adduces the basic rules of venous blood sampling, methods of facilitating intake in patients with problematic veins, describes modern search technology and visualization veins.

Вступ. Вміння швидко та безпечно провести забір крові з вени - це важлива навичка для медичної сестри. На практиці здійснити вдалу венопункцію не завжди вдається з першого разу. Часто доводиться мати справу з пацієнтами, у яких «проблемні» вени.

Існує декілька способів як полегшити цю процедуру та зробити ії максимально комфортною для пацієнта.

Основна частина. Багато людей відчувають страх перед маніпуляціями, які пов'язані з порушенням цілісності шкіри. Це призводить до скорочення вен, i як результат - їх складніше знайти. Тому перед процедурою необхідно створити максимальний психологічний комфорт для пацієнта.

При виборі інструмента для забору крові краще надати перевагу не традиційному шприцу, а закритій вакуумній системі [1].

Взяття крові за допомогою шприца становить певну небезпеку для медичного персоналу - ризик поранення голкою. За статистикою 73 \% випадкових уколів голкою медичним персоналом відбувається при маніпуляціях зі шприцом. При заборі крові за допомогою шприца часто виникає гемоліз еритроцитів, що призводить до спотворення результатів; неточний об'єм проби крові та неточне змішування з хімічними реагентами теж впливає на результат аналізу; нерідко відбувається проливання проб крові та ін. [2].

Переваги використання вакуумних систем:
- голки вакуумних систем значно тонші, порівняно з голками на звичайних шприцах, тому вени менше травмуються;

- при взятті крові за допомогою шприца медичні сестри затрачають в середньому 5-10 хв на маніпуляцію, а при користуванні закритою вакуумною системою цей час скорочується до 3-5 хв;

- безпечність для медичних працівників і пацієнтів у зв'язку з відсутністю контакту з кров'ю пацієнта;

- стандартизація - точне співвідношення об'єму крові та кількості реагенту;

- підвищення якості зразків сироватки та плазми крові;

- зручність і простота процедури (час взяття крові в одну пробірку становить всього лише 5-10 с, можливість швидкого використання двох і більше пробірок для різних аналізів без повторного введення голки);

- вакуумні системи для забору крові краще підходять для пацієнтів з тонкими і глибоко розташованими венами;

- скорочення кількості лабораторних помилок і повторних аналізів;

- психологічний ефект для персоналу і пацієнтів [3, 8].

Як правило, забір крові проводять з серединної ліктьової вени, яку досить легко знайти. Якщо вену не видно, ії можна напальпувати. Для цього краще використовувати вказівний палець. Не варто пальпувати вену великим пальцем, оскільки в ньому відчувається

(c) В. А. Славопас, 2016

44 ISSN 2411-1597. МЕДСЕСТРИНСТВО. 2016. № 4 
пульсація, яка заважає це зробити. Здорова вена повинна бути м'якою на дотик і пульсувати в такт серцевих скорочень, наповнюючись кров'ю і спадаючи. Не варто використовувати для пункції недостатньо гнучкі та ламкі на дотик вени. Потрібно уникати тих місць, де вени розгалужуються, або сходяться разом, оскільки в цьому випадку збільшується ризик підшкірної кровотечі.

При заборі крові з вени часто доводиться мати справу з тонкими, ламкими венами і стоншеною шкірою. В людей похилого віку значно зменшується вміст колагену та еластину в шкірі, внаслідок чого вона стає тонкою; також стоншується шар підшкірно-жирової клітковини, послаблюється імунна система. Все це підвищує ризик травми, кровотечі з місця венопункції, утворення гематом. Пацієнти, які хворіють на хронічні захворювання, часто проходять повторні обстеження та госпіталізації, внаслідок частих венопункцій на венах можуть утворюватися рубці, формуються дрібні капіляри-колатералі, з'являються тонкі, ламкі вени, які погано підходять для пункції [9].

Існують певні способи, які полегшують пункцію тонких вен і захищають стоншену шкіру від травматизації:

- при можливості необхідно використовувати голку меншого діаметра;

- не туго накладати джгут;

- при пункції вени голку потрібно вводити практично паралельно шкірі - це знижує ймовірність наскрізного проколу вени;

- обов'язково натягнути шкіру над веною, щоб вона не ковзала;

- не використовувати боковий доступ до вени, проколювати шкіру над веною, щоб голка не змістила вену.

Ділянки, з яких не бажано проводити забір крові:

- під рубцями і шрамами;

- в ділянці опіку;

- на руці, з того боку, де була ампутована молочна залоза;

- під синцями, гематомами, саднами;

- біля ділянок, уражених інфекцією;

- на тій руці, де встановлений катетер, або судинний трансплантат;

- над ділянкою, в яку проводилось внутрішньовенне вливання.

При виконанні взяття крові з вени на аналіз навіть досвідченим медичним сестрам не завжди вдається з першого разу попасти у вену. Згідно зі статистикою, в 40 \% випадків вдала венопункція виконується лише з другої спроби, а то й з третьої, четвертої. На допомогу медичним сестрам можуть прийти сучасні технології [4].

Портативний безконтактний пристрій для візуалізації периферичних вен значно полегшує пошук вен у проблемних категорій пацієнтів - опікових хворих, онкологічних хворих при проходженні хіміотерапії, пацієнтів, які тривалий час отримують внутрішньовенні вливання, в пацієнтів з ожирінням, новонароджених дітей та ін. Цей прилад значно скорочує час пошуку вени в критичних ситуаціях, знижує травматизацію тканин. Прилад оснащений малопотужними лазерами, що абсолютно безпечні для пацієнта, зате при наведенні приладу на шкіру відразу можна виявити вени, навіть самі тонкі. Застосування приладу для візуалізації периферичних вен дозволяє скоротити час, затрачений на взяття крові з вени вдвічі, а також здійснити венопункції з першого разу, не травмуючи пацієнта [5].

Окуляри з технологією 3D-візуалізації - сучасний високотехнологічний пристрій - дозволяють медичній сестрі з першого разу попасти у вену. Окуляри випромінюють інфрачервоні хвилі, що здатні проникати в товщу тканин завглибшки 10 мм. Промені поглинаються гемоглобіном венозної крові, але відбиваються артеріальною кров'ю, яка насичена киснем. Завдяки цьому медична сестра чітко бачить вени на руці пацієнта, що дозволяє їй практично безпомилково здійснити венопункцію. Це особливо актуально у ситуаціях, які вимагають швидкого і точного попадання у вену. Окуляри з технологією 3D-візуалізації одягають поверх захисних медичних окулярів.

Проте найбільшим недоліком сучасних технологій $\epsilon$ їх висока вартість, що на даному етапі практично унеможливлює їх введення в державні заклади охорони здоров'я. У той же час втілення сучасних досягнень науки і техніки в приватних клініках - це елемент конкуренції в боротьбі за пацієнта і високу якість послуг. Тому в медичних закладах приватного сектору поступово відбувається втілення сучасних медичних технологій та застосування новітньої медичної апаратури $[6,7,10]$.

Висновки. Існує пряма залежність між втіленням інноваційних технологій в практичну діяльність медичних сестер та якістю надання сестринської допомоги. Чим більш технологічний процес, тим більше часу приділяється самому пацієнту, тим вища якість сестринського обслуговування.

Застосування інноваційних технологій в щоденній практичній діяльності медичної сестри і, зокрема, 
при взятті крові з вени дозволяє виконувати роботу більш професійно, забезпечує комфорт і безпеку для

\section{ЛІТЕРАТУРА}

1. Сучасний стан здоров'я народу та напрямки його покращання в Україні : аналітично-статистичний посібник / В. М. Коваленко, В. М. Корнацький, Т. С. Манойленко [та ін.]. - К., 2005. - 140 с.

2. Справочник по лабораторным методам исследования / под ред. Л. А. Даниловой. - СПб. : Питер, 2003. - 736 с.

3. Медицинские лабораторные технологии : в 2 т. / под ред. А. И. Карпищенко. - СПб. : Интермедика, 2002. - 600 с.

4. Иванова О. В. Перспективы совершенствования и развития сестринского дела в Пермском крае / О. В. Иванова // Главная медсестра. - 2010. - № 3. - С. 16-24.

5. Островская И. В. Медицинские сестры и инновационные технологии в здравоохранении / И. В. Островская // Медицинская сестра. - 2009. - № 3. - С. 4-9.

6. Учайкина О. Н. Совершенствование работы сестринского персонала в частной медицинской организации / пацієнта і для медсестри, дозволяє швидко та якісно реалізовувати лікувально-діагностичний процес.

О. Н. Учайкина // Медицинская сестра. - 2013. - № 3. C. 48-54.

7. Шарабчиев Ю. Т. Ресурсосберегающие механизмы развития медицинской науки: инновационные проекты и теоретические исследования в медицине / Ю. Т. Шарабчиев // Медицинские новости. - 2003. - № 11.

8. Назаренко Г. И. Клиническая оценка результатов лабораторных исследований / Г. И. Назаренко, А. А. Кишкун. - М. : Медицина, 2006.

9. Кишкун А. А. Руководство по лабораторным методам диагностики / А. А. Кишкун. - М. : ГЭОТАР-Медиа, 2007.

10. J. W. Ross, DJ.Boone Assessing the effect of mistakes in the total testing process on the quality of patient care [Abstract 102]. Martin L Wagner W Essien JDK eds. 1989 Institute of Critical Issues in Health Laboratory Practice 1991 DuPont Press Minneapolis, MN. 